\title{
Social Entrepreneurship, An International Perspective
}

\author{
Jol Stoffers ${ }^{1,2}$, Agus Gunawan ${ }^{1,2}$, Anne Kleefstra ${ }^{1}$ \\ ${ }^{1}$ Zuyd University of Applied Sciences, Research Centre for Employability, Sittard, The Netherlands \\ ${ }^{2}$ Business Administration Department, Faculty of Political and Social Sciences, Parahyangan Catholic University, Bandung, Indonesia \\ Email: jol.stoffers@zuyd.nl
}

How to cite this paper: Stoffers, J., Gunawan, A. and Kleefstra, A. (2018) Social Entrepreneurship, An International Perspective. Open Journal of Social Sciences, 6, 10-24.

https://doi.org/10.4236/jss.2018.610002

Received: September 6, 2018

Accepted: October 7, 2018

Published: October 10, 2018

Copyright $\odot 2018$ by authors and Scientific Research Publishing Inc. This work is licensed under the Creative Commons Attribution International License (CC BY 4.0).

http://creativecommons.org/licenses/by/4.0/

\begin{abstract}
Entrepreneurship is an age-old concept, but the recent years have seen several varieties on the traditional entrepreneur. Take, for instance, the independent professional. The common denominator among all of these different types of entrepreneurs is their personal objectives and vision. This paper zooms in on one specific type: the social entrepreneur. This entrepreneur's primary goal is to generate and realise solutions for social issues. The organisation run by the social entrepreneur justifies its existence by their ideas, ardour and compassion. Social entrepreneurship is often associated with young change-makers who are idealist. Global Entrepreneurship Monitor (GEM) surveys in 58 countries show that it is the case in Middle East and North Africa, sub-Saharan Africa, and Western Europe. However, it is not the case in Eastern Europe, Latin America and the Caribbean, South-East Asia, Australia, and the United States of America [1]. This paper will explore the meaning of the concept of social entrepreneurship, the social entrepreneur's characteristics, the new working formats that facilitate social entrepreneurship, the power of networking, the positioning of social entrepreneurship, and its organisational design.
\end{abstract}

\section{Keywords}

Social Entrepreneurship, Business Studies

\section{What Is a (Social) Entrepreneur?}

To grasp a proper understanding of social entrepreneurship, it is the concept of entrepreneurship that first requires clarification. Entrepreneurship is a term that has been around for some centuries, mostly within the context of "business ventures" [2]. It is often described as the process of starting a business [3] [4]. Martin and Osberg [2] are more specific and describe it as "the combination of a 
context in which an opportunity is situated, a set of personal characteristics required to identify and pursue this opportunity and the creation of a particular outcome." This definition focuses more on entrepreneurship as a certain type of behaviour and can be seen as appealing, since it encompasses personal characteristics that are of an overarching importance for entrepreneurship as an occupation. Godin [5] describes entrepreneurs as initiators; they use money to build a profitable business that is larger than themselves. "The goal of the entrepreneur is to build an entity, something that can grow and thrive once it's moving".

The extensive list of characteristics of an entrepreneur will be addressed later in this paper. First up for consideration is an example of an entrepreneur, followed by an exploration of social entrepreneurship.

\subsection{Best Practice}

An entrepreneur pur sang is Richard Branson, a British businessman and founder of the Virgin Group, which comprises different types of enterprises. He started Virgin Records, a music label, in his university days. He later began an airline, Virgin Atlantic. Branson is known for his outlandish actions and slogans. For instance, Virgin Atlantic, as like any other airline was struggling with the problem that its passengers absconded the pepper and salt mills. Yet, while other airlines have meanwhile replaced them with cheaper alternatives, Branson has held onto his mills. The pepper and salt mills have been baptised Wilbur and Orvil (after the Wright brothers). Branson had Wilbur and Orvil engraved with the text "pinched from Virgin Atlantic" and they have become true collector's items. Wilbur and Orville became one of the most successful campaigns ever started by Branson's company [6]. Branson is an entrepreneur who takes initiative, makes mistakes, starts again, and does not quit. Another example is his multiple attempts to fly around the world in a hot air balloon. Although he has not managed as of yet, he has achieved great results. Branson distinguishes himself not only by his hippie type of looks and his reputation as enfant terrible, but also and especially by his energetic appearance, his unique way of working, and the enjoyment that he shows in his work. He has changed the lives of people all around the world with his numerous initiatives and the charities he supports-or, as Richard Branson himself puts it: "If you aren't making a difference in other people's lives, you shouldn't be in business-it's that simple." His clear objective thus also comes to the fore in his vision, which is something that is key to social entrepreneurs.

\subsection{What Is a Social Entrepreneur?}

Although entrepreneurship has been around for ages, the term of social entrepreneurship has only been used in the literature for the past few decades. Yet it is a frequently studied concept that has been given various definitions. Fowler [7], for instance, defines social entrepreneurship as "the creation of viable (socio-) economic structures, relations, institutions, organizations and practices that 
yield and sustain social benefits." Hibbert, Hogg and Quinn [8] on the other hand, regard it as "the use of entrepreneurial behavior for social ends rather than for profit objectives, or alternatively, that the profits generated are used for the benefit of a specific disadvantaged group." Seelos and Mair [9] in their turn describe social entrepreneurship as "the creation of social value through innovative, entrepreneurial business models." It is compelling that each definition includes the creation of value in the area of socio-economic issues. Social entrepreneurship is therefore also often viewed as an altruistic way of running a business, for instance by starting new initiatives, mobilising volunteers or generating new knowledge. According to Carlsson [10], new knowledge is the main driver behind innovation in the advanced economy and it is the entrepreneurs' duty to translate this innovation, through their initiatives and business, into economic development. GEM defines a social entrepreneur as "an individual who is starting or currently leading any kind of activity, organisation or initiative that has a particularly social, environmental or community objective". In terms of narrow definition, social entrepreneurship is "organizations must be driven by social value creation rather than value capture, and be market—rather than non-market-based" [1].

\subsection{Best Practice}

Tom van de Beek is a social entrepreneur and the cornerstone of copious initiatives. His organisation, "The Tipping Point" reflects his belief in creativity, imagination, originality, and resilience whereby man can become part of nature rather than domineer it. "The Tipping Point" uses its projects to push people in the positive direction towards a sustainable future [11]. "The Tipping Point is that magic moment when an idea, trend, or social behavior crosses a threshold, tips, and spreads like wildfire," according to Gladwell [12]. "The Tipping Point" is at the cradle of a great many initiatives, such as the "KantoorKaravaan" or "Office Wagon Train", an altered mobile home that provides people the opportunity to co-exist with nature in a responsible way. The "I Love Beeing" project also originated from "The Tipping Point". This project aspires to promote awareness and positive action in order to protect bees, as they are dying at an increased rate. Since this endangers our food supply, it is high time for people to take action. Tom van de Beek is now a well-known social entrepreneur, leader and visionary who uses his business not only for personal fulfilment, but also to stimulate and realise social change-all whilst achieving superb results [13].

\subsection{The Why of a Social Entrepreneur}

This paper details the emerging belief that entrepreneurship emerges from the need to contribute to the solution of a social issue, whereas the "classic" or conventional entrepreneur focuses on running the business itself and the building of a financially healthy enterprise with the possibility of growth. Generation of solutions and solving social issues are not focal points for the conventional entrepreneur. A social entrepreneur, on the other hand, shares the characteristics of a 
standard business owner in the area of "an innovative and financially viable company", but despite the objective of owning a successful business, their primary goal is still to generate and realise solutions for social issues. Their enterprise's existence is justified by their ideas, passion and compassion. Social entrepreneurship is about seeking and implementing innovative and sustainable solutions for a social, health or environmental issue. The prerequisite for sustainable entrepreneurship is indeed a financially healthy business, but the true success of a social entrepreneur is measured by the return on society they have realised.

Social entrepreneurs make major contributions to their community and society in a wide range of vital areas and use the principles of entrepreneurship in order to arrive at ingenious solutions for complex and persistent social problems [14], as does Tom van Beek in this example. The social entrepreneur takes the role of a leader, a visionary who motivates others in their environment to contribute to set objectives in order to make the world a little better. This can also be recognised in all of the examples of social entrepreneurs that will be reviewed in this paper.

\section{Characteristics of a Social Entrepreneur}

According to Drayton [15] [16], a social entrepreneur is not unlike any other regular entrepreneur. What then are the characteristics of a conventional entrepreneur, and the specific traits of a social entrepreneur that distinguish them from the rest?

When it comes to entrepreneurs, a frequently asked question is whether they are born or made-nature or nurture. The question has been under investigation for over 40 years, yet no answer has been found, albeit that a number of specific characteristics have been determined. Entrepreneurs themselves have, moreover, written a myriad of books on entrepreneurship in which a number of personal characteristics come to the fore that can also be identified in inspiring examples. Steve Jobs said: "see the opportunities in life's setbacks"-identify chances rather than focus on misfortune and learn from them. A certain degree of creativity is desirable here in order to grab and use these chances light-heartedly.

Entrepreneurship requires that the familiar is abandoned and a leap into the unknown is made. Muller [17] believes the leaving of the established comfort zone to be the first step towards entrepreneurship; this requires an entrepreneur to have guts and nerve to step from the beaten path and face the adventure. They will soon find themselves at a stage where they will have to fight for their business, where learning, failure and discovery are key if they are to arrive at the correct business model. It is possible to see new objectives at this stage. The final stage will be the business's golden perspective. Certainly at the second, but also at the first and third stage, unexpected problems or, as Nassim Nicholas Taleb [18] puts it, "black swans" will loom. Black swans are unexpected events. In order to cope with them, a certain degree of inventive problem-solving is required. After all, an entrepreneur needs to be able to quickly and flexibly deal with the unexpected. They require agility.

Furthermore, it is important to know when to quit. An entrepreneur is al- 
lowed to make mistakes. Better yet, they must make them. Mistakes are the best learning materials. Even the most famous entrepreneurs fail regularly and see this as a crucial factor lending to their success. It is important, however, not to persist with these failures too long-a successful entrepreneur knows when to quit an idea. For both the start-up and the cancellation of a project, an entrepreneur must dare to take risks, be able to deal with fear, but above all have the guts to take the step [19].

"Every master was once a disaster" - Permanent Beta. An entrepreneur has to start somewhere; you cannot excel in one day. Entrepreneurship requires endurance and patience, which makes it so important for them to have a stimulating network of people who know how to motivate them when they are at their wits' end or about to throw in the towel after the umpteenth disaster. It is not always easy, but perseverance will eventually lead to results. Naturally, it is also essential for them to enjoy what they do, face and learn from the challenge and be able to see the fun in this too.

Summarising this into a number of entrepreneurial traits, entrepreneurs must have the ingenuity to come up with an idea and overcome problems; have the nerve and guts to start; dare to take risks and go beyond their comfort zone; muster the endurance and patience to persevere when failure looms; see the opportunities that present themselves and experiment; fail and learn in order to constantly develop further; and possess agility and a creative problem-solving abilities whilst being able to play with the rules.

\subsection{Best Practice}

Oprah Winfrey is an example of an entrepreneur in heart and soul. She has started multiple booming businesses and her world-wide influence has changed lives. Do bear in mind though that Oprah started out with nothing and worked her way up to become one of the world's most successful entrepreneurs. Apart from her thriving initiatives, she has also tried her hand at countless things without success. She has taken risks and made mistakes. Yet, she believes that every entrepreneur should spend an hour each day learning something new. Experimentation, reading, hobbies and sports present challenges leading to the discovery of new things. According to Oprah, there is no better investment.

\subsection{Characteristics of a Social Entrepreneur: The Big Five Model}

The big five model also reflects the aspects of learning, curiosity and experimentation. Drafted by McCrea and Costa [20], it is well known among psychologists and generally accepted as the leading personality model for the clarification of people's characteristics. The big five traits are: openness, orderliness, extraversion, altruism, and neuroticism. Each of these traits can in turn be divided into different characteristics. Zhao and Seibert [21] have concluded, on the basis of the big five model, that entrepreneurs do indeed differ from other people in three characteristics. Entrepreneurs score significantly higher on the characteristic of openness. They are more open to new experiences, more curious, more 
innovative, prepared to change, sensitive, revolutionary, and inquisitive. They also score higher on orderliness, which comes with characteristics such as self-discipline, dedication, reliability, tidiness, keeping agreements, and purposiveness. Thirdly, entrepreneurs score considerably lower on neuroticism or emotional instability. That is to say that entrepreneurs are better at coping with stress and dealing with fears. Emotionally stable people are self-assured, relaxed, balanced, can deal with fear, and are commonsensical. For the characteristics of extraversion and altruism, on the other hand, no differences were found between entrepreneurs and non-entrepreneurs.

\subsection{What Makes the Social Entrepreneur Different?}

Social entrepreneurs in turn differentiate themselves in some respects from conventional entrepreneurs. For instance, the social entrepreneur is always geared towards solving societal issues. Drayton [15] [16] finds: "A social entrepreneur has the same core temperament as a business entrepreneur, but a social entrepreneur uses his or her talent to solve social problems on a society-wide-scale." In other words, social entrepreneurs are not entrepreneurial for their own financial benefit, but for the benefits of others, as Martin and Osberg [2] put it. Dees [3] regards social entrepreneurs as "social change agents", who create social value, continually look for opportunities, focus on innovation and adaptation, are not restrained by limited resources, and have a great sense of responsibility. Social entrepreneurs prioritise their social, health, or environmental goals over financial goals. Bosma et al. [1] state that "Even though social entrepreneurs do not always make a trade-off (e.g. short-term financial returns may be needed to create long-term social impact), many social entrepreneurs recognise the dilemma and continuously consider the potential financial impact for the organisation (value capture) against the social impact for their society and the environment (value creation)". In all of these sources, it is the importance of the societal issue and the social value formed by the social entrepreneur that comes to the fore. Between $50 \%$ and $70 \%$ of operational social entrepreneurs are "value creators" [1]. So, it is difficult to differentiate sharply the distinction between social entrepreneurs and entrepreneurs. Based on GEM interviews with approximately 150,000 adults in 49 countries during 2009, Terjesen et al. [22] state that in South-East Asia, most social entrepreneurs assist the poor by enabling them to undertake better livelihood activities or run their enterprises viably, something they do by launching business (or for-profit) enterprises.

Another trait shared by social entrepreneurs is the collaboration that they seek and the network that they build around themselves and put to use in order to realise their goals. Social entrepreneurs commonly go about their business in a swarm or tribe. These concepts will be further explained in the paragraph about networking. However, working in a swarm or tribe does not only require certain things from a social entrepreneur, such as the possibility to take leadership, collaboration, and communication, but it also raises the importance of reputation. A social entrepreneur must stand out, and be considered as special. Reputation 
or, as Hunt [23] refers to it, social capital is of inestimable value to a social entrepreneur. Social capital provides work, but also a network to fall back on whenever needed. This is another crucial aspect of the social entrepreneur's network. Actions are naturally key to any entrepreneur; if entrepreneurs do not pull themselves out of the idea development stage and expect others to bring the idea to fruition, little will happen. The step to action is, therefore, essential, but it is also the most scary-especially the first time [5] [17]. On the other hand, the entrepreneur is enthusiastic about their idea and believes in it. This eventually makes them take the initiative and instigate a move. This belief also helps the entrepreneur survive and endure during difficult times [17]. The sooner the movement occurs with a well-considered idea, however, the greater the chances of success [5].

According to Guclu, Dees and Anderson [24], social entrepreneurship always starts with a promising idea emerging from personal experiences or the awareness of social needs, social properties, and change (see also Figure 1). Although ideas can be powerful, the authors believe it is primarily about the translation of ideas into concrete possibilities and solutions. It follows that social entrepreneurs greatly benefit from a strong analysis. They argue that the chance of success is influenced by the underlying theory about return on society, a business model, and a viable resource strategy.

Nowadays, social entrepreneurs put substantial effort into measuring the social and environmental impact of their social venturing activities [1]. The GEM surveys also shows that about five in every ten individuals involved in social entrepreneurship reinvest profits towards the social goals set by the activity, organisation or initiative. More than a third of the world's social entrepreneurial ventures rely on government funding, while family and banks are also important sources of funding for social entrepreneurs. Social entrepreneur in Southern and Eastern Asia and MENA commit the highest level of own investment (estimated over $60 \%$ ) while the lowest share of own investment is in sub-Saharan Africa-roughly $30 \%[1]$.

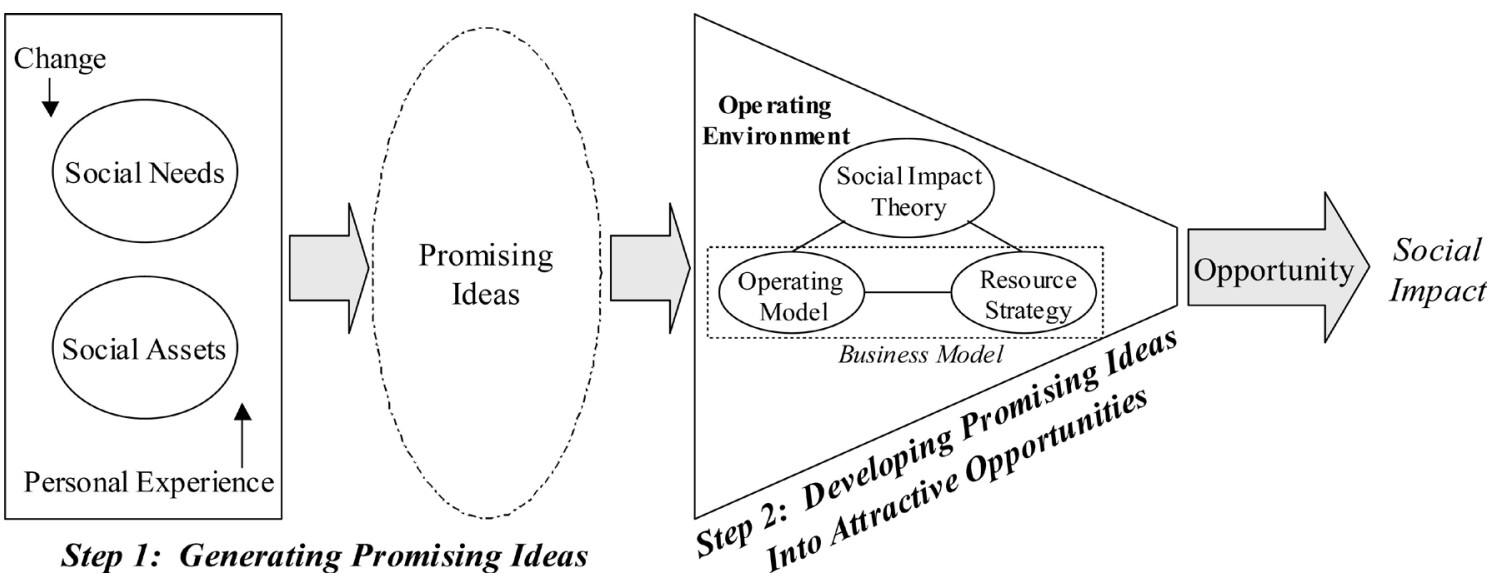

Figure 1. The opportunity creation process [24]. 


\section{The Power of the Network}

Social capital takes central stage in social entrepreneurship. A social capitalist is someone who builds and maintains a community. In her book, Hunt [23] refers to social capital as "whuffie". The "whuffie" induces financial capital to start flowing. In other words, it is the network and the maintenance of this network that will eventually result in finances flowing into the bank account of the entrepreneur with social capital. Social capital is the currency that results from their reputation. They can lose or earn it through positive or negative actions, contributions to the community by their good or bad repute in three ways: be friendly, network well, or be special [23].

Social entrepreneurial networkers think in terms of giving. Do as you would be done by; if you do good by others, the good comes back to you. The gift economy's principle is the complete opposite of the market economy's: the more you give, the more social capital you accrue. In the market economy, your money is gone when you give it away. Saving money is, on the other hand, more advantageous; whereas social capital only rises in value if it circulates through the community [23].

\subsection{Best Practice}

Social entrepreneur Nils Roemen uses the Internet to deploy his network and encourages other to do so too. Together with Herman Dummer, he developed the "durftevragen" (daretoask) national network and multiple other initiatives in the sharing economy. He believes there is more than enough for everyone in this world, the problem is merely in the way it is divided. This message is reflected in his presentations as a speaker, in his initiatives, and in the "erisgenoeg" ("thereisenough") magazine. He does not do it all alone, but works with a network of people around him. Soon after coining the idea of daretoask, meetings were organised where people met in order to help one another. Daretoask is now a well-known hashtag on Twitter. Thousands of people use \#daretoask or \#durftevragen on a daily basis to solve problems, find student digs, or receive answers to IT questions. People like to help each other and rarely ask the question "what do I get in return?". Having the nerve to ask questions and allowing others to help is a way of putting social value in society to good use. When people work together, they can move mountains. In Estland, for instance, 50,000 volunteers joined forces in 2008 and cleared the entire country of litter in 5 hours. The fulfilment of needs is in the asking. Furthermore, it allows for the sharing of assets with others who need them. Daretoask helps people to capitalise on social value more cleverly, so that everyone can contribute to solving scarcity-the problem of division-in this world [25].

\subsection{Networks}

As mentioned above, most social entrepreneurs collaborate in networks. They cluster in a so-called swarm. This gathering organises itself in a natural way. A 
swarm is a form of collective intelligence that assembles by itself. There are abundant examples of swarms in the animal world, such as bees, ants and starlings. The continual, quick interaction enables a swarm to flexibly and adaptively respond to changes in the environment. This makes a swarm a powerful network that is more fluid than hierarchical organisations. "Swarms, you can't beat them, but you can join them" [26].

An example of a swarm that has gathered quite rapidly is the community Do-It-Yourself Drones, with almost 20,000 members to-date. The swarm members write software, design and test hardware, and share all their findings with one another. The swarm held so much expertise in such a short space of time that the community came up with an ambitious objective. They took the Raven military drone $(€ 25,000)$ as their example and aspired to construct a qualitatively comparable drone for just $1 \%$ of the price of a Raven. They managed to do so with breakneck speed and within a year the Quadcopter was on the market for a cost price of $€ 220$ [27].

The basis of swarms is self-organisation: order and structure emerge without any form of central direction through, for instance, division in tribes, sub-groups within the great swarm that collaborate intensively. In the DIY Drone community, a swarm of people worked together towards a common goal, but sub-groups fixated specifically on one project. They shared the knowledge that they acquired through their project with the rest of the swarm, after which another tribe in this swarm used it for the further development of their own project. This way, the swarm jointly worked towards their objective. "A tribe is a group of people connected to one another, connected to a leader, and connected to an idea" [28]. A tribe can have a single leader, but leadership can also be shared. This leadership can also differ in terms of content. Both a tribe's and a swarm's organisation is geared to self-direction, so that they can flexibly respond to one another and the environment. For social entrepreneurs it is a way of seeking collaboration in a network of like-minded people.

\subsection{Technology}

Technology has given social entrepreneurship an enormous boost. Social network websites provide social entrepreneurs the possibility to unite and collaborate. The social networks are resources that they can put to imaginative use in order to achieve the best results. Technology has also paved the way for the open source movement. The open source movement publishes developments and knowledge online specifically to receive response and thus work together to arrive at the best and most efficient innovation. Furthermore, the Internet enables social entrepreneurs to involve a wider audience in their activities and even mobilise them to take action, such as the occurrence in Estland in 2008. As mentioned, social entrepreneur Nils Roemen put the technology to ingenious usage, but other social entrepreneurs have meanwhile also discovered the usefulness of the worldwide web and technological developments. Another feat of technology 
is crowd funding, which has provided the financial support for many entrepreneurial initiatives. This all would have been impossible without technology and the Internet.

If everyone has access to the same resources, however, it becomes increasingly more problematic for an entrepreneur to distinguish themselves. A network as well as their expertise allows the entrepreneur to stand out, "but most of all, I'm betting it's your attitude," Seth Godin says. It is their behaviour that serves as the entrepreneur's business card and can lead to valuable partnerships and projects or, as Hunt [23] puts it, social capital.

\section{Positioning of the Social Entrepreneur}

Social entrepreneurship has a cross-domain nature [29], since social entrepreneurs position themselves at the interface of the public and private realms. Their organisations often vary widely, which makes it difficult to put them all into one unequivocal definition. It is always one person, a social entrepreneur, who takes the initiative to set up the organisation. Social entrepreneurship as such is not directed by the government, but initiated bottom-up.

Social entrepreneurs contribute to growth, wealth, and general welfare. $\mathrm{Ob}$ viously, as in any generalisation there are exceptions as well as poor imitators who solely focus on generating money or image rather than innovating or realising a return on society out of sheer passion and still refer to themselves as social entrepreneurs [30]. But true social entrepreneurship pivots around social innovation and renewal in a range of areas like education, culture, health care, the environment, and business. Based on GEM surveys on 167.793 respondents from 58 countries, about five out of ten social entrepreneurs reinvest profits towards social goals [1]. Social entrepreneurs aim to achieve a return on society through new and innovative organisation. This makes it complicated sometimes to pinpoint their position, as does the fact that they do not restrict themselves to one specific area, but tend to operate in a great many fields.

\subsection{Best Practice}

An example of innovative organisation is the way Esther Jacobs designed her initiative. With Coins for Care, she has made the world of charities wobble on its foundations. When the Euro was introduced in 2002, Esther Jacobs came up with the idea to collect foreign coins that people had lying around at home and which were now useless, for charity. Without any experience with major collections and also without any budget, she simply set to work. Her action raised over $€ 16$ million, which she divided among 140 charities. After the distribution, however, it became clear that not every charitable organisation could properly justify where the money had gone and issues became known that could not really bear the light of day. Esther Jacobs then started her next initiative, which aimed to get more transparency in the world of charities. "Left Over Currency" still collects Dutch guilders and other currencies [31]. Esther Jacobs is an exam- 
ple of a social entrepreneur who operates in several fields in the way she prefers. Her innovative working method and innovation of those of others are central to her realisation of a return on society. Now known as the "no excuses" lady, she is operating worldwide in order to make the world a little better in her own way.

\section{Can Social Entrepreneurship Be Typified as a Form of Organisation?}

Mintzberg has described 5 basic organisational configurations [32] [33]: the simple structure, the machine bureaucracy, the professional bureaucracy, the division structure, and adhocracy. In practice, these 5 configurations are never found in their pure form, but organisations do usually tend towards one of them. It is argued here that none of these 5 configurations apply in general to the social enterprise. Mintzberg mentions that there might be a sixth configuration in which the organisation's ideology is a powerful force behind its mission. He refers to it as the missionary configuration. It has its own coordination mechanism-socialisation or standardisation of values along with a similar design parameter-indoctrination-as well as the organisation's sixth main component-ideology [32] [33].

Given the standardisation of values, it could be concluded that it is a form of bureaucracy. The missionary organisation, however, has a loose structure where absolute loyalty to the mission is key and the checks of the conventional bureaucracy are not needed to have staff do as expected. This loyalty can be maintained by trusting everyone equally. It needs a simple mission and a simple technological system. The characteristics of the pure missionary configuration can be described as follows: virtually no direct supervision or standardisation of skills, work or output, so minimal hierarchy; no technological structure; hardly any middle-management; no formalisation, action planning or checks on results. Aslander and Witteveen [26] typify it as an easycracy: a place that is not governed by bureaucracy, rules, or protocols, but by the ultimate goal.

The social entrepreneur's business model revolves around the social value they create. The business model is also fully harmonised with the culture of the environment. The following case is a clear example.

I Made Mahendra Budhiastra [34] has created a business model that is fully attuned to the Balinese culture, since he has incorporated his environment's standards and values. He developed the idea of Karma Karana, which focuses on a sustainable hospitality industry in Bali through consultancy, business development, and an IT system. Kama Karana encourages the Balinese community to start their own businesses. Bali has numerous major hotel chains. All this tourism causes a large amount of pollution and the wages in the industry are low. The new entrepreneurs pay a monthly fee depending on the size of their business and become registered in a system. The user gets access to a database of scientific consultancy and expertise in business that helps solve complex problems they stumble upon. The system has been developed in collaboration with 
local universities. Karma Karana also provides additional services, such as the brand management of the new businesses. Its profits will be invested in the community-in infrastructure, education, and health care, for instance. Karma Karana's business model is based on Budhiastra's [34] Four Chakra Business Model (see also Figure 2).

The Four Chakra Model contains four elements vital in product development in the environment of Bali. The first is spiritual: God provides earth with resources that can be used for the further advancement of man. It follows that something should be given to God in return (Tri Murthi). The second is nature, a scarce and finite element. The third is the social element; people are social beings and should be treated with respect and justice, regardless of their status in society. Finally, there is authenticity; each person is different and thus has different needs, even though they have the same status as a human being [34].

This business model is an excellent example of adaptation according to the environment where the business is located-which is an important facet in social entrepreneurship.

\section{Conclusions: Challenges for Social Entrepreneurs}

As any other entrepreneur, social entrepreneurs are faced with challenges. They let themselves be led by ardour and compassion for certain societal issues. This draws their attention away from their business operations. Financial health is just as important for social entrepreneurs as any other business owner if they are to stay in business and continue to do so in the long term. For many social entrepreneurs this is a complication, since their focus is on a return on society rather than finances. It is also important to stay concentrated. True impact results from concentration. Every entrepreneur fixates on the aim they would like to achieve, but when a social entrepreneur's business goal is not perfectly clear or they deal with too many different projects at the same time, this will be at the expense of the final results. When they have mobilised a great number of people to take a certain action, this might be too difficult to hang on to in the long term. It is not easy to keep people involved in the initiative in order to create a sustainable business.

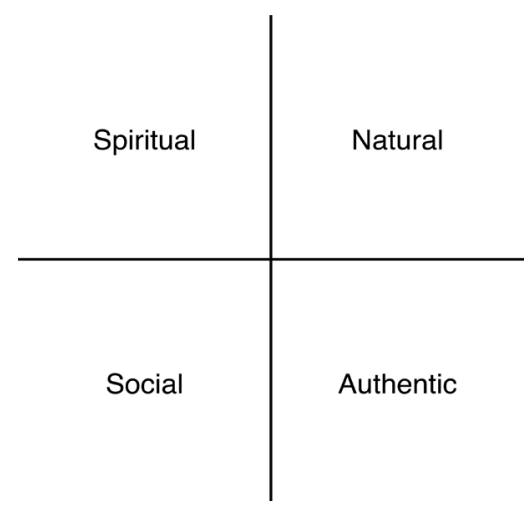

Figure 2. Four chakra business model for product development [34]. 
Entrepreneurship is, moreover, full of paradoxes. Business owners are often stigmatised as free spirits with little time for rules. Qualities like discipline, routine, and order are, however, equally welcome assets; they provide the calm and freedom that is essential to entrepreneurship [17]. Other examples of the diverse range of paradoxes are that entrepreneurs should persevere and never give up, but also know when to quit; focus, but not on merely one thing, as variation is also good; safeguard their own income and the business's financial health, but not be led by them; etc. The list is endless. All of these things are, indeed, important and these paradoxes will never disappear, but it is up to the entrepreneur to find the correct balance. Whatever the balance is, it is up to them personally. This will always be a voyage of discovery.

\section{Conflicts of Interest}

The authors declare no conflicts of interest regarding the publication of this paper.

\section{References}

[1] Bosma, N., Schøtt, T., Terjesen, S. and Kew, P. (2016) Global Entrepreneurship Monitor 2015 to 2016: Special Report on Social Entrepreneurship. Global Entrepreneurship Research Association, London.

[2] Martin, R. and Osberg, S. (2007) Social Entrepreneurship: The Case for Definition. Stanford Social Innovation Review, Spring, 1-39.

[3] Dees, J. (2001) The Meaning of Social Entrepreneurship. Kauffman Center for Entrepreneurial Leadership, Stanford University, Stanford, CA.

[4] Alvord, S., Brown, L. and Letts, C. (2004) Social Entrepreneurship and Societal Transformation, an Exploratory Study. Journal of Applied Behavioral Science, 40, 260-282. https://doi.org/10.1177/0021886304266847

[5] Godin, S. (2015) Poke the Box: When Was the Last Time You Did Something for the First Time? Penguin Group, London.

[6] Omdenken (2016) Peper \& zout. [Pepper \& Salt.]

http://www.omdenken.nl/peper-zout/

[7] Fowler, A. (2000) NGDO's as a Moment in History: Beyond Aid to Social Entrepreneurship or Civic Innovation? Third World Quarterly, 21, 637-654. https://doi.org/10.1080/713701063

[8] Hibbert, S., Hogg, G. and Quinn, T. (2001) Consumer Response to Social Entrepreneurship: The Case of the Big Issue in Scotland. International Journal of Nonprofit and Voluntary Sector Marketing, 7, 288-301. https://doi.org/10.1002/nvsm.186

[9] Seelos, C. and Mair, J. (2004) Social Entrepreneurship: The Contribution of Individual Entrepreneurs to Sustainable Development. IESE Business School, University of Navarra, Navarra, Spain.

[10] Carlsson, B. (2011) New Knowledge: the Drivingforce of Innovation, Entrepreneurship and Economic Development. In: Audretsch, D.B., Falck, O., Heblich, S. and Lederer, A., Eds., Handbook of Research on Innovation and Entrepreneurship, Edward Elgar, Northampton, MA. https://doi.org/10.4337/9781849807760.00022

[11] Stichting The Tipping Point (2016) Visie. [Vision.]

http://www.thetippingpoint.nu/?page_id=19 
[12] Gladwell, M. (2000) The Tipping Point: How Little Things Can Make a Big Difference. Back Bay Books, New York.

[13] Jansen, F. and De Witt, A. (2015) Duurzaamheid van binnenuit: Hoe een nieuw, bruisend bewustzijn de wereld verandert. [Intrinsic Sustainability: How the World Is Changed by a New, Sparkling Conscience.] Promotheus Bert Bakker, Amsterdam.

[14] Zahra, S.A., Rawhouser, H.N., Bhawe, N., Neubaum, D.O. and Hayton, J.C. (2008) Globalization of Social Entrepreneurship Opportunities. Strategic Entrepreneurship Journal, 2, 117-131. https://doi.org/10.1002/sej.43

[15] Drayton, W. (2002) The Citizen Sector: Becoming as Competitive and Entrepreneurial as Business. California Management Review, 44, 120-133. https://doi.org/10.2307/41166136

[16] Davis, S. (2002) Social Entrepreneurship: Towards an Entrepreneurial Culture for Social and Economic Development. Ashoka, Amsterdam.

[17] Muller, M. (2015) Entrepreneurship Is an ABC. Business Contact, Amsterdam.

[18] Taleb, N.N. (2007) The Black Swan: The Impact of the Highly Improbable. Penguin Books, London.

[19] Godin, S. (2011) The Dip. Hachette Digital, London.

[20] McCrae, R.R. and Costa, P.T. (1987) Validation of the Five-Factor Model of Personality across Instruments and Observers. Journal of Personality and Social Psychology, 52, 81-90. https://doi.org/10.1037/0022-3514.52.1.81

[21] Zhao, H. and Seibert, S.E. (2006) The Big Five Personality Dimensions and Entrepreneurial Status: A Meta-Analytical Review. Journal of Applied Psychology, 91, 259-271. https://doi.org/10.1037/0021-9010.91.2.259

[22] Terjesen, S., Lepoutre, J., Justo, R. and Bosma, N. (2011) Global Entrepreneurship Monitor: Report on Social Entrepreneurship Executive Summary. Global Entrepreneurship Research Association.

[23] Hunt, T. (2009) The Whuffie Factor: Using the Power of Social Networks to Build Your Business. Crown Publishing Group, Danvers.

[24] Guclu, A., Dees, J. and Anderson, B. (2002) The Process of Social Entrepreneurship: Creating Opportunities Worthy of Serious Pursuit. Center for the Advancement of Social Entrepreneurship, Duke University, Durham.

[25] Roemen, N. and Koerst, F. (2011) Daretoask: The Power of Social Overvalue. Haystack, Zaltbommel.

[26] Aslander, M. and Witteveen, E. (2010) Easycracy: The Future of Work and Organisation. Sdu Uitgevers bv, Den Haag.

[27] Aslander, M. and Witteveen, E. (2015) Never Finished: A New View at the Fundamentals of Live, Work, School, Healthcare, Government and Management. Business Contact, Amsterdam.

[28] Godin, S. (2008) Tribes: We Need You to Lead Us. Hachette Digital, London.

[29] Franssen, B. and Scholten, P. (2007) Social Entrepreneurship in the Netherlands. Van Gorcum, Assen.

[30] Baumol, W.J. (2011) Invention and Social Entrepreneurship: Social Good and Social Evil. In: Audretsch, D.B., Falck, O., Heblich, S. and Lederer, A., Eds., Handbook of Research on Innovation and Entrepreneurship, Edward Elgar, Northampton.

[31] Jacobs, E. (2016) Coins for Care. http://estherjacobs.info/coinsforcare/

[32] Mintzberg, H. (1992) Structure in Fives: Designing Effective Organizations. Prentice Hall, Upper Saddle River. 
[33] Mintzberg, H. (2009) Tracking Strategies: Toward a General Theory of Strategy Formation. Oxford University Press, New York.

[34] Budhiastra, I.M.M. (2016) The Karma Karana. Stenden University, Leeuwarden. 